\title{
Ori, Ritual and Yoruba Drama of Existence
}

\author{
Lekan Balogun \\ Victoria University of Wellington, New Zealand
}

\begin{abstract}
By their nature, rituals cannot provide scientific link between cause and effect, yet for their functional value they produce results. The Yoruba understanding expressed through belief in Ori as a potent vehicle through which man confronts life draws attention to this reality. Drama has also functioned in underlining this fact. The paper engages this Yoruba ritual concept and makes a case for an authentic Yoruba (African) value by exploring this aspect of the people's ritual, through an exploration of Wole Soyinka's Death and the King's Horseman. By examining the character of Elesin Oba and his son, Olunde, showing how each comes to the understanding and the crucial perception of their individual Ori, and the exploration of their iwa, the paper shows the essential place of that aspect of the people's belief in their lives and worldview.

Keywords: archetypes, consciousness, cosmos, performative art, ritual.
\end{abstract}

\section{Introduction}

In the introduction to the essay, "Prayers to the Orisha: a look at Santeria", Elizabeth Caudillo asks "Who owns your head?"(2)[1].This is one of the most significant ontological questions, which the Yoruba worldview concerns itself with and, indeed, provides an answer to. Ori is made up of the prefix "o" that stands for the individual, male/female and the suffix "ri" which means "to perceive" and both freely translate as "seat of perception", or in Western theological term, "seat of consciousness", or in Taoism, the "unknowable I" at the centre of self-awareness"(Awo Fatunmbi, 45)[2]. Within the body is enclosed the source of individual energy that produces both the intellect and the emotion, which are themselves influenced by the Ase, the spiritual power that provides the alignment with the Orisha, each of which is directly connected to individual being, or Ori, as the case may be. In coming to this understanding, which points at a crucial question that bothers on the intricate relationship between the two opposing binary; life and death, spirit and matter, the Yoruba are able to develop a number of rituals through which they grasp the subject that appears very simple, yet elusive. To them, ritual is one of the essential and valued methods of knowing. Ritual thus comes across as a means of connection to the source of man and, at the same time, a means to maintaining a balance in this earthly plane. Drama has also functioned as an important process of coming to this reality. This paper examines Yoruba ritual concept embedded in Ori, as "a site of a person's essential nature (iwa) and her/his ase" (Drewal et al 26)[3]. Soyinka's Death and the King's Horseman is also analyzed as paradigm to discuss the Yoruba rite, in order to show the importance of this cultural belief to the people and how they perceive themselves.

\section{Background: Ori, concept of Selfhood in Yoruba worldview}

Ori occupies a central position in Yoruba thought and worldview. The concept encapsulates the people's attempt at grasping selfhoood and the very intricate and important ritual that surrounds it. In the chapter "Proverbs and the Ifa Concept of Self", Awo Fatunmbi does a brilliant explanation of the concept of Ori that helps to highlight our argument in this paper. Orisha, the spiritual forces in Nature are each and collectively identified with $\mathrm{Ori}$ which is "the essence of consciousness in all of its manifestations"(Fatunmbi 85). Taking it from its root, Fatunmbi explains that $O r i$

Suggests the gathering together or picking up of hidden Forces embedded in and forming the Nature of all things in general, and human identity in particular [...It] suggests that the Universal Creative Energy, which is intrinsic to all things in Creation, is fragmented or unstructured until Ori (Spirit of Inner Self), Iponri (Spirit of Higher Self), and the Ase (Life Force) are in complete alignment and harmonious union (85).

Our idea of Ori emanates directly from Ifa, the Orisha scripture which has, within its kernel, both spiritual and terrestrial origins bestriding the two worlds; of spirit and matter. According to Fatunmbi, Ifa teaches that "the world is a balanced system that functions with its own internal guidance system that maintains harmony and growth" (39). In order to grasp this sacred internal order, every individual "must live in accordance with its inherent principles" (40). And, living by the principles requires a very strong understanding that emanates directly from being conversant with the Ori, what it means, embodies and the ways it is approached.

According to Falokun, contained within the teachings of Ifa is the fact that "when the self experiences alignment with Orisa, the balanced connection between the physical, emotional and spiritual occurs" (40).In 
other word, the spiritual exerts considerable influence on our perception, attitude and action, but by aligning with the Orisha as the Source of Being, one is able to grasp the control over self and thus tap the ase needed for that highly important consciousness. In the words of Drewal et al, "Ase is given by Olodumare to all of his creation", and in actual fact, "existence is dependent on it (ase); as the power to make things happen and change", aside from its most important part, which is the "sacred characteristic of social ramification reflected in its translation as 'power', 'authority' and 'command'"(16).

In its simplest form, ase is equally reflected in physical objects and can be seen to be at play in verbal arts such as music, chant, invocation etc and in visual arts. One major example is the Ifa, which involves that very intricate and "formal means of organizing diverse powers, not only to acknowledge their autonomy but, more importantly, to evoke, invoke, and activate diverse forces, to marshal and bring them into the phenomenal world" (16). And, in order to structure society and its relationship with the other world, the recognition and autonomy of the ase, either of persons and gods, remain very crucial (16). This point emphasizes the rite and ritual essence of the Ori, especially from the Yoruba worldview. A very crucial ritual associated with Ori among the Yoruba is the rite called "Imori (Knowing-the-Head)", through which, as Drewal et al explain "the person undergoes elaborate instruction and preparations in order to be able to receive, that is, become a vessel for the spiritual presence or ase of his/her divinity during trances that are an essential part of Yoruba worship" (32-3). The fact that this ritual is usually performed as soon as a child is born underlines the fact of its sacred importance. It also suggests the level of awareness that the Yoruba mind displays about the intricate, yet balanced and symbiotic relationship between the world of the living and the unborn; the relationship between spirit and matter, in all of its immensity and how such balance must be maintained at all times.

\section{Stages in Ori and the road to Selfhood}

Achieving a balanced connection between the tripartite; physical, emotional and spiritual self occurs at different locations of the Ori from which Fatunmbi identifies the Iwaju ori, Atari and Ipako (46). Iwaju Ori, that is, "the forehead", embodies a very deep esoteric meeting point that also serves as the point of contact between the consciousness of the external world and individual consciousness, regarded as "Third Eye", in certain mystical concepts (45-6); this allows for some kind of mystical vision and perception that transcend the level of the ordinary.

Atari, the "top of the head", suggests an area of consciousness that transcends beyond perception in both time and space; a place often regarded as the most central of the places wherein Source of Creation itself is deposited. It is the area called Nirvana in Yoga, an equivalent, so to speak, of what Ifa simply terms "Lai-Lai" (47). Ipako, "the base of the skull", is the transcendent place of connection between the Orisha and the individual consciousness (47). Drewal et al make an elaborate explanation of this particular phase of consciousness, which occurs during the rites of Imori (Knowing-the Head) at childbirth or at the Orisha initiation at adulthood (32), in order to find out from what Orisha the individual is descended or whether $\mathrm{s} / \mathrm{he}$ is from either the mother's or father's lineage. According to them, "the person undergoes elaborate instruction and preparations in order to be able to receive, that is, become a vessel for the spiritual presence or ase of his/her divinity during the trances that are an essential part of Yoruba worship" (32-3).

Drewal et al's further explanation also draws attention to Fatunmbi's claim that since it is the Ori inu that is invoked in such a ritual process, usually the "head is shaved, bathed, anointed, inoculated, and painted with spiritually potent substances and symbolic colors possessing the ase to attract and direct spiritual forces in particular ways" (33). At the conclusion of such an intricate ritual of knowing and possession, a certain reaction is often always expected, which proves the efficacy of the entire process and confirms the connection the people still have with their ancestry and the Orisha. Drewal et al explain that "When possession occurs, the Yoruba say that the gods have gun ("mounted") their worshippers. They are known as elegun orisa ("gods mounts"), or esin orisa ("horses of the gods")(33). This situation provides the answer to Caudillo's question about who owns the individual's head and to what divinity s/he responds in Yoruba spiritual perception.

\section{Ori in the context of Yoruba Drama}

Writers play a major role in the dissemination of myths as part of their unusual sensitivity to the sacred, a characteristic which places them as "chief priests" in the ritual of transition from one age to another; from one system of belief and values to a new one. This "priestly" role finds expression in different forms. In drama particularly, which draws its material from ritual, we are often made to share in the experience of the "spiritual" through the struggles of the characters who, having to confront this "numinous passage", in order to achieve their goal, or yet perish in the process of trying, help us to also come to terms with our own shared values. Yoruba drama derives from this kind of ritual. Ori functions significantly in this drama of "cultural selfapprehension" (Olaniyan 43)[4] and ritual imagination. Soyinka's Death and the King's Horseman lends itself to this explanation and understanding, through the characters of Elesin Oba and his son, Olunde. In the play we are confronted with two contrasting assertion of will---the Ogun Will---through actions that emanate from both 
conscious and unconscious projection of the Ase, directly derived from the perfect understanding or realization of selfhood by each of the characters in the dramatic experience. In his analysis Soyinka underlines the will of Ogun as the 'true essence'---at the same time his flaw---in the mould of Aristotelian tragic conception found in unbridled pride. Nietzsche himself explains this idea within the ambience of the logic of the law of karma; "whoever, in pride of knowledge, hurls nature into the abyss of destruction, must himself experience nature's disintegration"(61)[5].

Ogun's will is its flaw; the bravery to confront and chart a path for the other divinities in the clogged void, the "thick undergrowth of matter and non-matter", the "chthonic realm" (a term from Nietzsche), resulting in its being torn to several pieces, as contained in Yoruba mythology. It is from this ritually saturated world that Soyinka draws his rich-textured 'drama of the gods', which one encounters in his signature plays like The Road, Death and the King's Horseman or even Bacchae of Euripides. The willing sacrifice of the lone hero will later resurface in The Strong Breed and the epic poem, "Ogun Abibiman". Soyinka insists that the ritual archetype, a term borrowed from Carl Jung can best be suited to explaining this category of drama, which draws from ritual, the 'drama of the gods', since the enactment by man, is merely to establish what has already been there in the spiritual consciousness of mortal being, as inspired from the cosmology.

\section{Explication of Ori ritual through Soyinka's Death and the King's Horseman}

Death and the King's Horseman remains Soyinka's most important, if not distinguished play, in which the "African world" in what he describes as the "The Fourth Stage"[6] is dramatically presented. Even though the conflict that the playwright sets up in the play seems to be the collision between traditional system represented by Elesin Oba and colonial/foreign presence represented by Pilking, Soyinka however emphasizes that the play should not be approached from such too common simplistic binary of interpretation. Rather, he posits a deeper and ritualistic position that derives from the Yoruba worldview, especially belief in the existence and interaction of the three worlds. In his words, he argues that "the confrontation in the play is largely metaphysical, contained in the human vehicle which is Elesin and the universe of the Yoruba mind---the world of the living, the dead and the unborn, and the numinous passage which links all: transition"(Author's Note)[7].

In another essay, Art, Dialogue and Outrage, Soyinka describes the play as his effort to “"epochalise' History for its mythopoeic resourcefulness" (128)[8]. Providing a historical source to the play is in line. On Tuesday, December 19, 1944, the Alaafin of Oyo, Oba Siyanbola Oladigbolu 1, died after a reign of thirty-three years. The commander of the King's stables, Olokun Esin Jinadu, had enjoyed a privileged position during the Alaafin's reign, and it seemed to have been assumed by the people of Oyo that he would follow his master by committing suicide. On that day, Jinadu was delivered a message at the village of Ikoyi near Oyo. About three weeks later, on January, 4, 1945, he returned to Oyo, dressed himself in white and began dancing through the streets towards the house of Bashorun Ladokun which, according to the people's tradition, is a customary prelude to committing suicide. It was apparently anticipated that he would end his life by the established means of taking poison or allowing a relative to strangle him, which is a choice entirely left to him. At this point however, the British colonial officer in authority at Oyo intervened by issuing an order to the Bashorun that Jinadu should be apprehended and taken to the Residency. This order was carried out and Jinadu was taken into custody. When words of the arrest spread, Jinadu's youngest son, Muraina killed himself in his father's place.

This account is enough for Soyinka. With minor amendments, in matters of detail, sequence and, of course, characterization, Soyinka dramatizes this ritual of supreme sacrifice, by relying more on language and characterization that are spiced with music, which is a major vehicle of narration. As Maduakor explains "it is not the truth of history that Soyinka is concerned with but with the validity of a basic metaphysical question" (272)[9]. Macebuh also explains that there is a complementary interaction between history and myth, and "may suggest that Soyinka's persistent mediation on myth is an attempt to reveal the primal foundations of African culture, and therefore of history"(201)[10]. Soyinka infused the epic narration with dances and drumming to depict the Yoruba metaphysical world. This drama provides us with a major "ritual" that attempts to explain the working code of Ori rites in explicit terms through the way Soyinka presents his characters to us. In this particular instance, we draw our attention to Elesin Oba and his son, Olunde.

Ori guides whoever it wills, and, this all-important fact of Yoruba belief is perfectly played out in the encounters both Elesin Oba and Olunde had with external cultures, external thoughts and persuasions as symbolized by two significant situations in the play. First, let's see how Olunde explains his own "encounter" with foreign system of culture and education. Soyinka first hints at Olunde's perfect understanding of the tradition into which he was born unlike his father who seems overwhelmed by sated desire to prolong his stay as the very crucial moment of ritual veneration of his people and tradition draws closer. In his meeting with Jane Pilkings (wife of the District Colonial Officer), who is dressed in the Egungun costumes of his people, Olunde could not stomach his dismay at the sacrilege, albeit committed by colonial ignorance of his people's customs; while Jane sees this 'act' as a good cause since it is to welcome His Highness the Prince, he expresses his displeasure. 
As an England- based and trained medical doctor returning home after hearing the news of Alaafin (King)'s death and the demand on Elesin Oba, his father, who is expected by tradition to commit ritual suicide, one would ordinarily expect to be introduced to an idealistic young man whose attitude to such "barbaric customs" as Jane describes the ritual, would suggest a total change of lifestyle compared to his people's culture, or at best that he shows some measure of "refinement", exactly what she initially expects by considering him the best example of an educated African. Her consternation is thus understood, when he talks of the validity of the ritual process his father is about to perform and how significant it is to the people and their world. In response to her expression of shock over his 'wild' and 'unusual' acceptance of his father's 'suicide' attempt, he expresses the validity of that living tradition, the interface between ori and ase, deployed through $i w a$. His language is bold, lucid and mature as he tells her;

"He has protection. No one can undertake what he does tonight without the deeper protection the mind can conceive. What can [anyone] offer him instead of his peace

of mind, in place of the honour and veneration of his own people?"(23) [emphasis mine].

By "protection", we might construe Olunde's idea in the form of a perceived connection between the 'carrier' that his father, Elesin, is in relation to the people for whom and on whose behalf he is so regarded and the sacred duty that he is being waited upon to perform, so that the balance, which has become shaky and unstable as a result of the departure of the Alaafin can be restored to normalcy by his own willing supreme sacrifice. Further, it tells us of the level of awareness that the young man has about the spiritual essence of his being, how he connects to the cosmos of his people's world and what is expected of an individual, especially an initiate of the mysteries that he believed or supposed that his father is. To such a mind, it is conceivable, but not to a European mind like Jane's. Despite her seeming 'genuine' concern for the young man's emotional state overshadowed by her apparent repulsion for such "barbaric" rites, Olunde's utterance says otherwise

OLUNDE: Don't think it was just the war. Before that even started I had plenty of time to study your people. I saw nothing, finally, that gave you the right to pass judgement on other people and their ways. Nothing at all.(24).

If this statement can be considered a way of expressing the awareness of his ori, the next might serve to provide knowledge of his decision to use his ase in a manner that he perfectly understands

All these things are part of it. And anyway, my father has been dead in my mind for nearly a month.Ever since I learnt of the King's death, I've lived with my bereavement so long now that I cannot think of him alive. On that journey on the boat, I kept my mind on my duties as the one who must perform the rite over his body. I went through it all again in my mind as he himself had taught me. I didn't want to do anything wrong, something which might jeopardize the welfare of my people (25).

On the other hand, Elesin Oba appears to us as an antithesis of this kind of resolve, in the way he toys with sacred duty despite having the knowledge of the enormity of the task ahead. We first encounter him in a passage through a market in its closing stages with the attendant economic activities, which foregrounds the play as a spatial representation of the world of the living with its materialistic tendencies. Soyinka's choice of opening the play in a market, especially at the closing period of its activities functions on several levels, namely, drawing attention to the symbolism of the world as a market place, as a metaphor for the stark reality of loss and emptiness that accompany a wasted journey and, in some ways, how a life disconnected from the knowledge of how the ori and ase mutually function might end up eventually: in loss and misey.

Umukoro attests to the cultural charm of the market this way; "it is defined as the microcosm of life, that swarm of the world in its small compass, a warm vital throbbing haven for a variety of human activities"(33)[11].This explains Elesin's choice of the market as his point of departure because, according to him, "This is where I have known love and laughter away from the palace" (40), and he tells Olohun-Iyo, who tries to warn him; "come then. This market is my roost when I come among the women, I am a chicken with a hundred mothers. I become a monarch whose palace is built with tenderness and beauty (40). The Praise singer heightens the excitement of Elesin-Oba's entrance into the market, with his lyrical chant to eulogize, caution and recollect the past in order to strengthen his will for the ritual suicide that will ensure the continuity of life of the community. He gives an insight into Elesin's mission in the market with this rendition; "O-oh, you hear my companions? That's the way the world goes. Because the man approaches a brand new bride he forgets the long faithful mother of his children (9).

The Praise-singer's recollection of the past; "In their time, the world was never tilted from its grove, it shall not be in yours"(10), seems at first to give him courage. But, he also cautions him; "They love to spoil you, but beware. The hands of women also weakens the unwary"(10). However, Elesin fantasizes, with thought of tarrying over the pleasures of life at that crucial moment that should be devoted to spiritual musing and effort to connect his Ori with the task for which he had been born and raised all his life through using his ase to fulfill it. 
"This night I'll lay my head upon their laps and go to sleep. This night, I'll touch feet with their feet in a dance that is no longer of this earth. But the smell of their flesh, their sweat, the smell of indigo on their cloth, this is the last air I wish to breathe as I go to meet my great forebears"(10).

However hard Iyaloja, the leader of the market, tries to direct Elesin's attention back to the enormity of the ritual task that he wants to perform, it seems there is already a disconnect between him and the other world; a succinct expression of a total lack of the spiritual connection between his position, the duty expected of him by the people and the overall interaction between his ori and the use to which he should put his ase. It goes to show our earlier assertion that Soyinka's use of the market already divested of its richness and life, is a metaphoric rendition of Elesin's pathetic race of life. In a strong term, couched in apt proverb, Iyaloja warns him of the consequences of toying with sacred duty; "eating the awusa (walnut) is not as difficult as drinking water afterwards"(9); but what he desires is not what she thinks is necessary, for in response, he tells her "who does not seek to be remembered? Memory is the Master of Death, the chunk in his armour of conceit [...] let the considerate traveler shed of his excessive load, all that may benefit the living"(9). Iyaloja is not so besotted as not to know to what he refers, so she warns him again; "you wish to travel light. But be sure the seed you leave on it [the earth] attracts no curse"(10). Pilking, the Colonial Officer's intervention, what Soyinka himself describes as "a catalytic intervention merely"(Author's Note), comes at such a 'timely' moment when will and playful demeanour, sacred duty and sated desire clash in one heart divested of knowledge necessary for connecting with a past that waits anxiously for that very crucial reunion. Iyaloja does not spare Elesin of the morbid stench that oozes from his betrayal of his ancestors. She scolds him without any reserve. Besides, she wonders if Elesin cannot understand or simply decides to toy with the 'simple' order of their spiritual life. She cannot reconcile why he fails to listen to the voice that he needed to; "tell me, you who were once Elesin Oba, tell me, you who know so well the cycle of the plantain: is it the parent shoot which withers to give sap to the younger or, does your wisdom see it running the other way?" But, being already disconnected to his Ori, as it appears, Elesin cannot understand how to tap his ase. How can he even if he does understand the need to after, as Iyaloja rightly describes, his becoming an; "emptied bark that the world once saluted for a pith-laden being."

To make up for Elesin's sacrilegious act and to prevent the calamity that may befall the community, Olunde, commits suicide. With this act, Olunde disappoints his colonial sponsors who thought that his exposure to western culture will change his perception of an age-long tradition. However, Olunde, as Dasylva observes, is Soyinka's ideal character; he epitomizes virtue, vis-a-vis honour, positive sense of duty, self-sacrifice or selfless courage and wisdom (31)[12]. Olunde's act corresponds to the Igbo concept of the Ori, as contained in their belief in Chi, an individual's personal god. Ogunyemi explains this symbiosis

Chi/Ori is the quidditas inside the human body, that part that cannot be detected but that we know is there [...].Chi/Ori is recognized as a powerhouse lodged within the individual, a recourse accessible, in danger or crisis, to the owner willing to use it. As primary mediating, Chi/Ori labors to engender the psychological moment efficacious in reaching one's goal, particularly in a time of stress (35-6)[13].

Symbolically, in this ritual drama, Soyinka explicates the expression of consciousness about Ori and the use to which ase can be put, suggesting that the offshoot supplants the root; the young son wrenches honour from the hands of his father by coming into the knowledge of his personal ontology. George Brandon explains that "it is ritual which allows humans to traverse all the categories of being through the manipulation and communication of ase [...] and allowed people to have access to the accumulated wisdom of the deities and the dead as paradigms for solving current problems" (qtd in Caudillo,3)[14].

Such very descriptive expression also draws attention to the metaphor of the "Not I Bird" as a poetic rendition meant to serve the traditional function of an epic simile (Dasylva 23). It symbolizes how Soyinka draws attention to Elesin's fear and lack of courage at that very crucial moment of ritual veneration. Above all, it shows his total lack of understanding regarding his Ori and the proper use of his ase. Elesin actually inadvertently admits his fear and ignorance; "I, when the Not I Bird perched on my roof, bade him seek his nest again, safe without care or fear. I unrolled my welcome mat for him to see. Not I flew happily away, you'll hear his voice, No more in this life time-You all know what I am (14). Dasylva explains what this implies is that "when the Not I Bird (i.e. fear) pays him a visit, he encourages the bird (fear) to make a nest there without fear or threat to its life"(32). Elesin therefore willingly allows fear, propelled by lust for vanity, to lead him on away from his sacred duty to his people. Soyinka's sensibility to the symbolic use of Yoruba idiomatic expression is amplified by Iyaloja's scolding of Elesin here; "How bolding the lizard struts before the pigeon when it was eagle itself it promised us he would confront" (67).

The powerful imagery to note, according to Dasylva, includes '“Lizard' a cold-blooded reptile which symbolizes the cowardly but boastful Elesin; 'Pigeon, symbolizing a relatively harmless and moral Pilkings; and the 'Eagle', a bird of prey and an agent of death, here symbolizing death" (42). In other words, Elesin's boldness 
before Pilkings is a mere face-saving device, having failed to confront death gallantly. Besides, a major point of attention which Soyinka seems to draw attention to is that instead of the old dying and getting supplanted by the young and fresh bud, it is the other way round. Pilkings humanitarian gesture suddenly becomes a tragic reordering of nature, with the old succeeding the young, and not the usual other way round. Iyaloja's summation-a fitting one actually-- captures the reality of the tragic loss and waste that Elesin's entire life has suddenly become in the sight of his people, especially a race, which knows the authentic value of history. By even committing suicide, he devalues his corpse even as much as his life had already been bereft of its value by the failure to venerate tradition, for which his entire life had been graciously prepared. Iyaloja remarks "He is gone at last into the passage but oh, how late it all is. His son will feast on the meat and throw him bones. The passage is clogged with droppings from the King's stallion; he will arrive all stained in dung."

\section{Conclusion}

In two related essays, Soyinka seems to underline the relevance of Brandon's claim, in relation to the explication of the worldview that expresses this idea of selfhood. First, he writes that "Yoruba drama [into which the play can also be classified] is the re-enactment of the cosmic conflict"(149-150), by which we might argue he(the Yoruba mind) grapples the knowledge inherent in the spiritual and how it conflicts with the physical in the effort to establish a place. In the other instance, he writes that "the concern of ritual theatre [the category into which the play can be also classified] in this process of spatial definition....must be seen as an integral part of man's constant efforts to master the immensity of the cosmos with his minuscule self'(40). When both Olunde and Elesin talk of honour and duty, we would understand that earning one through the other can only be achieved with understanding of the intricacies of the relationship between the spiritual and the physical. This brings to mind Kay, a character in the film, Season of the Witch who says "honour is not something to be dismissed or forgotten"[15]. Ori holds honour in its palms; it is only through the ase, that any man can possess it.

\section{Works Cited}

[1] Caudillo, Elizabeth Diane. Prayers to the Yoruba: A Look at Santeria, Spring 1994, Fall 1995.

[2] Fatunmbi, Awo Falokun. Iba'Se Orisa: Ifa Proverbs, Folktales, Sacred History and Prayer. Bronx, New York: Original Publications, 1994.

[3] Drewal, Henry John, Pemberton III, John and Abiodun, Rowland. Yoruba: Nine Centuries of African Thought and Art. Wardwell, Allen \&.New York: Centre for African Art, 1989.

[4] Olaniyan, Tejumola. Scars of Conquest/Masks of Resistance: The Invention of Cultural Identities in Africa, African-American and Caribbean Drama. New York and Oxford: Oxford University Press, 1995.

[5] Nietzsche, Frederick. The Birth of Tragedy. New York: Doubleday, 1950.

[6] Soyinka, Wole. Myth, Literature and the African World. Cambridge: Cambridge UniversityPress, 1976.

[7] Soyinka,Wole. Death and the King's Horseman. London: Methuen, 1975.

[8] Soyinka, Wole "The Fourth Stage: Through the Mysteries of Ogun to the Origin of Yoruba Tragedy" Art, Dialogue and Outrage Ed. Jeyifo, Biodun. Ibadan: New Horns Press, 1988.

[9] Maduakor, Obi. Wole Soyinka: An Introduction to His Writings. Garland Publishing Inc: New Yorkand London,1986.

[10] Macebuh, Stanley "Poetics and the Mythic Imagination" Critical Perspectives on Wole Soyinka Ed. James Gibbs. Washington, DC: Three Continents Press, 1980.

[11] Umukoro, Mattew "Poetry and Symbolism in Wole Soyinka's Drama". Ibadan: Review of Englishand Literary Studies, Dept of English, University of Ibadan,1990.

[12] Dasylva, Ademola Omobewaji. Understanding Wole Soyinka's Death and the King's Horseman. Ibadan: Sam Bookman Educational and Communication Services, 1995.

[13] Ogunyemi, Chikwenye Okonjo. Africa Wo/Man Palava: The Nigerian Novel by Women Chicago: Chicago University Press,1996.

[14] Brandon, George. Santeria from Africa to the New World, The Dead Sell Memories. Bloomington and Indianapolis: Indiana University Press, 1997.

[15] Season of the Witch. Dir. Dominic Sena. Relativity Media and Atlas Entertainment,2011. 